\title{
Senescense and dispersal under local climatic variations of bearded reedlings Panurus biarmicus at the southwestern limit of their European distributional range
}

\begin{abstract}
Climatic disturbances can determine variations in the body condition and body size in birds on time and hence affect he health status. This study confirms that Bearded reedlings Panurus biarmicus express this at small-medium time scales in a age-dependent form at least at semi-isolated local wetlands of Western Mediterranean. To determine body condition and body size, I took biometric measurements during ringing protocols and afterwards I opposed them to climatic variables in 1992-2009. Bearded Reedlings gained condition and lessen size on time as a response to changes of climate at a local scale in the form that wetter and milder local climates influenced negatively the outcome, and this was age dependent. Youngsters improve body condition and adults impair it. Number of adults ringed decreases on time in favour of a stronger condition of the more abundant juveniles. These age variations may reveal that these small populations are becoming senescent, suffering a weakening response that risks its survival. However, dispersal of some agegroups towards suboptimal novel areas could ameliorate this process.
\end{abstract}

Volume 3 Issue 3 - 2019

\section{Ignacio García Peiró}

Department of Ecology \& Hidrology, University of Murcia, Spain

Correspondence: Ignacio García Peiró, Department of Ecology \& Hidrology, Faculty of Biology, University of Murcia, C/ El Salvador, I7-4D.03203 Elche (Alicante), Spain, Tel: 0034965 45। 777, Fax:00 34965 42। 320, Email ignacio.peiro@yahoo.es

Received: May 01, 2019 | Published: June 06, 2019

Keywords: reed bird specialist, body traits, climatic outcomes, western mediterranean

\section{Introduction}

Amongst the Eurasian reed-marsh-dwelling passerines, the Bearded Reedling (Panurus biarmicus, $L$ ) is a remarkably dimorphic bird subject matter of selective forces. ${ }^{1,2}$ Its subspecific position and arrangement in Eurasia remained questionable in the old $^{3,4}$ and recognized as polytypic species. ${ }^{5}$ Since preceding 1960 's ${ }^{6}$ it spreaded in some European states ${ }^{7-10}$ so it was looked upon as a bird of "least conservation" concern. ${ }^{11}$ Even, in some countries it has reached a decline (e.g. The Netherlands). ${ }^{12}$ In the instance of Spain the species considers directly threatened ${ }^{13}$ or endangered ${ }^{14}$ and Eastern populations remain actually at risk of quasi-extinction or extinction. ${ }^{15-17}$ Concerning the effects of climate change on Bearded Reedling's populations in Europa, the abiotic effects on them in temperate areas reveals drastic downfalls in quantities combined to prolonged floods of reed-beds. ${ }^{18,19}$ In northern, cooler places, the growing of temperatures leads to more prolonged breeding seasons enabling more broods ${ }^{20}$ but in Western Mediterranean semiarid regions winter minimum temperatures and increments of annual rainfall causes decreasing in mist-netting annual indexes ${ }^{21}$ while in Central Mediterranean areas meteorological conditions appear not to be a serious component. ${ }^{22}$

Body condition and body size of birds are inter-connected ${ }^{23-25}$ and may rule as a significant proxy of health quality. This is because they signal senescence of populations, ${ }^{26-28}$ can be age-dependent, ${ }^{29-31}$ readily handled and measured in the field ${ }^{32,33}$ and afterwards statistically evaluated. ${ }^{34}$ Furthermore, it is proved that body traits to be of major importance to analyze extinction processes $\mathrm{n}$ bird's populations $s^{35}$ and may be influenced by isolation degree. Condition meets with body weight ${ }^{24,25}$ and body size relates with measures of external parts of the bird. ${ }^{36,37}$

Earlier studies in Bearded Reedling's regarding body condition and size present sex dependent constraints in size of yearlings during critical physiological demands as the complete moult ${ }^{38}$ and sex differences in some traits of juveniles which signal condition ${ }^{39}$ Sexratio of broods is not related with body condition in nestlings ${ }^{40}$ but colonial females are of considerably higher quality in body condition and size than solitary males. ${ }^{41}$

In this investigation, I try to analyse if some body traits of this species are age-dependent and if they are linked to annual fluctuations along time. I use measures of yearlings (juveniles or adults) collected from standardized ringing protocols $\mathrm{s}^{42}$ in a snall population in "El Hondo Natural Park" considered to be at the southernmost limit of the Western Europa. ${ }^{43}$

On doing so, I try to check the following hypothesis: 1) Bearded Reedlings tend to be persistently heavier and lighter on time 2) this effect is age-dependent: juveniles improve its condition linked to increases of rainfall and temperatures as outcome of climate change, 2) birds of a longer age (adults) impair it in reply to wetter and warmer climates and 3) The two previously hypotheses facilitate a differential dispersal that is age-dependent and enhances ability to some birds to form age groups to cope with novel habitats. Finally, these age discrepancies may reveal senescence by natural selection in this small population, experiencing a probed depressing process, which could put in risk its durability.

\section{Material and methods}

\section{The study plateau}

The south Alicante-Murcia wetlands complex in South-East Spain corner (Figure1) consists of four internationally protected wetlands: 1) El Hondo Natural Park ( $2400 \mathrm{Ha} ; 38^{\circ} 16^{\prime} \mathrm{N} 00^{\circ} 44^{\prime} \mathrm{W}$ ) is an inland man-made wetland constituted mainly by an inner deep reed-bed belt 
and outside a hard salt-marsh zone, 2) Santa Pola's saltpans Natural Park $\left(2570 \mathrm{Ha} ; 38^{\circ} 12^{\prime} \mathrm{N} 00^{\circ} 37^{\prime} \mathrm{W}\right)$ is a structure of saltpans with saline vegetation, 3) La Mata-Torrevieja Natural Park (3743 Ha; $38^{\circ}$ $01^{\prime} \mathrm{N} 00^{\circ} 41^{\prime} \mathrm{W}$ is a littoral saline lagoons complex surrounded by a zone of salt-marshes and 4) Mar-Menor Lagoon Natural Park (13500 $\mathrm{Ha} ; 37^{\circ} 50^{\prime} \mathrm{N} 37^{\circ} 34^{\prime} \mathrm{W}$ ) is a hyper saline coastal lagoon encircled by a narrow region of reed-beds and salt-marshes. They are distant among them about $10-50 \mathrm{Km}$. Since the surface of wetlands in Mediterranean has reduced about $50 \%$ since the preceding century, ${ }^{44}$ the early three groups can be treated as remnants of an enormous marsh swamp existent in southern Alicante in the ancient centuries at the catchments of Segura river basin, ${ }^{45,46}$ and where the genetic isolament could be high 88. Only El Hondo Natural Park and Santa Pola's saltpans Natural Park remain with tiny populations of Bearded Reedlings observed on previous 1970's. . $^{47,48}$ Climatic datasets from the study area (El Hondo Natural Pak) from 1992 to 2009 (N = 18) were collected $11 \mathrm{Km}$ NNE direction: total annual rainfall (248.7 \pm 156 $21.7 \mathrm{~mm})$, mean annual temperatures $\left(19.6 \pm 0.3^{\circ} \mathrm{C}\right)$. The annual total ammount of rainfall and annual mean temperatures set up a system of lowlands in Southern Alicante immerse in a semiarid plateau defined by a fragmented landscape with a deficient hydrologic system..$^{49,50}$

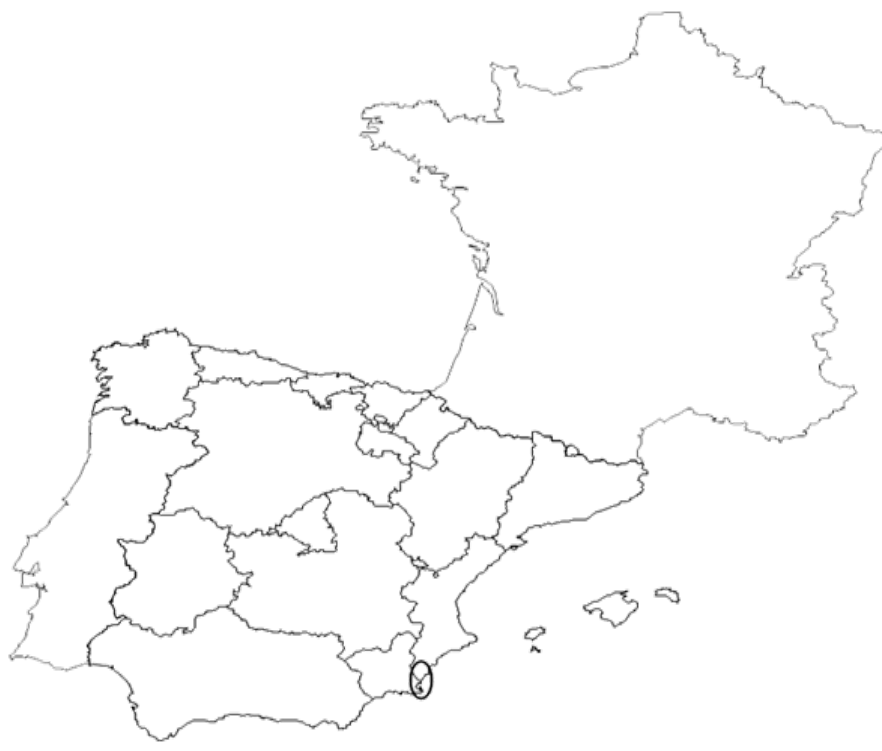

Figure I Study area plateau at South-Eastern Spain. Oval area corresponds to the south Alicante-Murcia wetland complex covering a surface of about $800 \mathrm{~km}^{2}$ and currently composed by agricultural and urbanized fragmented landscapes with medium-great spots of salt-marshes, reed-beds and open water in the remnants of the a great marshland named "Albufera de Elche" in the past centuries. ${ }^{46,49,50,88}$

\section{The population studied}

The small population of the Bearded Reedling studied, established at El Hondo Natural Park was monitored in 160-140 individuals in 1985-2006. ${ }^{16,45}$ According current count census (2017) it is expected to be quasi-extinct. ${ }^{17}$ Another short distant North Eastern tiny population of ${ }^{45}$ individuals in 2005-2006 is detected at the nearby Santa Pola's saltpans and currently considers extinct. ${ }^{17}$ Bearded Tits in El Hondo have been systematic trapped for ringing since 1991.42,51 No birds ringed in any other population have regularly been recovered here but short distant groups are definitely established inside El Hondo ${ }^{52,53}$ and observations in transitional fields of both wetlands (Els Carrrisars) have been carried out but Interchange among sites cannot be ruled out from ringnig data.

\section{Biometrics and population data}

In order to gather bigger samples sizes and not to differentiate by seasons (summer and winter), I got for first ringed birds $(\mathrm{N}=253)$ in 1992-1995,2002-2007 and 2009 (23 \pm 13 individuals per year, $\mathrm{N}=$ 11 years). Population was surveyed mainly in summer since $66 \%(\mathrm{~N}$ $=167)$ of them were ringed in March-October) and $44 \%(\mathrm{~N}=88)$ in November-February so population studied could be mainly breeder because 1) juveniles were the bulk 21 and 2) most adults were in complete moult. ${ }^{38}$

The right wing-length (maximum chord method and to the nearest $0.5 \mathrm{~mm}$ ), bill-length (to the skull and to the nearest $0.1 \mathrm{~mm}$ ), right tarsus-length (according to the bent method and to the nearest $0.1 \mathrm{~mm}$ ) were measured. ${ }^{32} \mathrm{I}$ also recorded the body mass (to the nearest $0.1 \mathrm{gr}$ ) with Pesola spring balance. Bearded Reedling is a highly dimorphic passerine on which adult males differ in colour from adult females. ${ }^{5}$ Juveniles males resembles to juvenile females but can be sexed by bill and iris color. ${ }^{32,54}$ Birds were aged as youngsters (juvenile plumage) or older (adult plumage after completing moult) and sexed according. ${ }^{32}$ I estimated body condition using the residuals of a regression of body mass on wing length. I used tarsus-length to provide the better estimator of body size instead of other skeletal measures ${ }^{37}$ since tarsus-length had a high correlation with wing-length. I determined data from observations of birds at nearby sites by local bibliographic notes. ${ }^{54,55}$

\section{Statistical analyses}

For statisitical analysis I used a Generalized Linear Model (GLM) ${ }^{56}$ Body indexes were entered in the model as separated dependent variables, age and sex as fixed variables and year and climatic variables (rainfall and temperature) as covariates. ${ }^{57}$ All variables were enclosed in the model with all their interactions. ${ }^{58,59}$ Climatic variables were chosen because in some Bearded Reedling's populations rainfall and temperatures result a proxy of productivity ${ }^{18}$ and breeding outcomes. ${ }^{20}$ Spearman correlations were used to verify relations of productivity in the life's tables with year. All statistical nalyses were implemented employing IBM SPSS v23 sofware. ${ }^{57}$

\section{Results}

Local rainfall increased significantly by $25.5 \%$ (see slope trend formula) in the expanded time scale 1992-2009 $(\mathrm{N}=18)$ and temperature increased not significantly in $0.6^{\circ} \mathrm{C}$ per year (rainfall $=9.613^{*}$ Year $18982.1 ; \mathrm{F} 1,16=7.285, \mathrm{P}=0.016$; temperature $=0.062 *$ Year -104.6 ; $\mathrm{F} 1,16=1.754, \mathrm{P}=0.204)$. This local scenario results in wetter and hotter years on time and it is slightly different at the global scenario for the present century at South-East Spain scale, which gives an increase of temperatures and a decreasing of rainfall. ${ }^{60}$ Wing-length was substantially related to body mass and explained a $26.5 \%$ of variance of the dependent variable (Body mass $=0.219 \cdot$ Wing-length $+0.168 ; \mathrm{r}=0.515 ; \mathrm{P}<0.001 ; \mathrm{d} . \mathrm{f}=236)$. GLM analysis (Table 1$)$ reveals that Bearded Tits lessen body condition but increase body size on time and this is linked to increments of temperatures and rainfall that is age-dependent in the form that juveniles improve condition in contraposition that adults that impair it. Number of adults ringed declined on time (Spearman $\mathrm{r}=-0.21 ; \mathrm{P}=0.861$; d.f $=15$ ) and the number of juveniles increased (Spearman $\mathrm{r}=-0.29 ; \mathrm{P}=0.289 ;$ d. $\mathrm{f}=15$ ) so productivity of juveniles per adult determined an increase along 1992-2006 (Spearman $\mathrm{r}=0.33 ; \mathrm{P}=0.224$; d. $\mathrm{f}=15$ ) all data analyzed from the life-tables of studies in the same site. ${ }^{61}$ 
Table I GLMAnalysis on dependent indexes (condition and size), independent fixed factors (age and sex) and covariates (year, total annual precipitation, mean annual temperature). Significant values $(P<0.05)$ are in bold

\begin{tabular}{|c|c|c|c|c|c|c|c|c|c|}
\hline \multirow[b]{2}{*}{ Variables } & \multirow[b]{2}{*}{ B } & \multicolumn{5}{|c|}{ Condition } & \multicolumn{3}{|l|}{ SIZE } \\
\hline & & X2Wald & df & $\mathbf{P}$ & Variables & B & X2Wald & df & $\mathbf{P}$ \\
\hline Intercept & 102.989 & 4.958 & I & 0.033 & & 198.579 & 6.886 & 1 & 0.019 \\
\hline Age & -17.53 & 0.045 & I & 0.836 & & -129.117 & 0.914 & I & 0.337 \\
\hline Sex & -18.877 & 0.016 & I & 0.75 & & 39.509 & 0.173 & I & 0.682 \\
\hline Rainfall & 0.056 & 7.224 & I & 0.055 & & -0.086 & 6.18 & I & 0.024 \\
\hline Temperature & 0.038 & 0.685 & I & 0.032 & & -0.03 & 0.249 & I & 0.734 \\
\hline Age*Sex & 0.737 & 0.519 & I & $0.47 \mid$ & & -0.429 & 0.394 & I & 0.677 \\
\hline Age*Year & 0.029 & 0.717 & I & 0.397 & & -1.036 & 0.382 & I & 0.537 \\
\hline Age*Rainfall & -0.015 & 5.027 & I & 0.025 & & 0.06 & 1.022 & I & 0.312 \\
\hline Age*Temp & -0.268 & 4.932 & I & 0.027 & & 0.039 & 0.146 & I & 0.702 \\
\hline Sex*Year & 0.017 & 0.418 & I & 0.518 & & 0.479 & 0.111 & I & 0.739 \\
\hline Sex*Rainfall & -0.06 & 1.474 & I & 0.225 & & -0.017 & 0.161 & I & 0.689 \\
\hline Sex*Temp & -0.703 & 1.402 & I & 0.236 & & -0.013 & 0.032 & I & 0.859 \\
\hline \multicolumn{2}{|c|}{ Age*Sex*Rainfall*Temp } & 5.575 & 3 & 0.134 & & -0.225 & 0.065 & I & 0.799 \\
\hline Deviance & 145.782 & & 219 & & & 317.562 & & 206 & \\
\hline Akaike (Aic) & 592.053 & & & & & 747.747 & & & \\
\hline
\end{tabular}

\section{Discussion}

This research involves a natural selection which is age-dependent and condition-size dependent, ${ }^{62-65}$ and that the population of Bearded Reedlings could confront with such variations and to cope with novel habitats, as adaptive process to climate change ${ }^{66}$ This study indicates that condition is really not sensitive to temperature but rainfall operates as a proxy of climatic variations affecting condition. ${ }^{67,68}$ Furthermore, the growing temperatures and rainfall influence condition of juveniles negatively and forces to smaller youngsters to make short trips towards outermost novel, more productive areas outside of wetland, considered foraging sites and where changes in morphological traits have been verified ${ }^{53}$ as occur in other reed-bed passerines which use suboptimal areas because the diversity of food is higher ${ }^{19,69}$ Contrarily, lighter and bigger youngsters after development from nest as chicks contribute to maintain in optimal dense areas inside of wetland making movements of longer distance from nesting and foragingmoulting areas $\left(5-13 \mathrm{~km}\right.$, own data of author and $\left.{ }^{52}\right)$. Probably Bearded Tits of younger age are more nomadic in its movements and they are associated to variable peaks of production of reed-seeds of better quality at sparse areas ${ }^{53}$ enabling observations towards other distant areas outside of the study area ${ }^{55,83},{ }^{85}$ falling inside the range of Iberian movements ${ }^{70}$ but at shorter distances.

Changes in wing shape during complete moult give adults more pointed wings enabling longer faster trips. ${ }^{42}$ Greater condition and smaller size of the more abundant youngsters at study area on time ${ }^{61}$ is a description that exist morphological adaptions to warmer climates as a skill to cope with an evolving environment, so phenotypic plasticity is favoured ${ }^{66}$ Rainfall is of crucial matter of abundance of birds at Mediterranean ecosystems ${ }^{71}$ but affects negatively condition of Bearded Reedlings at South-Eastern Iberian populations. Corresponds to this study, to indicate that in northern cold areas of
Europa, Bearded Reedlings benefit of climate warming favouring a protracted breeding seasons and facilitating higher productivity. ${ }^{20}$ This local scenario, contradicts with more healthy populations at inland wetlands of Central Iberia where the environmental conditions differ and where productivity and survival is higher. ${ }^{72}$ Shrinkage of body size with warmer climates is a universal rule in animals as an ecological response to climate change ${ }^{73-75}$ and it is consistent with the findings of this study. On the other hand consider it as a positive effect of phenotypic plasticity which is adaptive, ${ }^{76}$ but has exceptions. ${ }^{77,78}$ Due to the morphological constraints imposed by the environment at southern latitudes, the system of Panurus $^{80}$ at semiarid landscapes of South-East Spain it is considered as semi-isolated system where a surplus of individuals change its condition and $\operatorname{size}^{53}$ and senescence of populations is produced by impoverishment of body traits (see Great Tits Parus major). ${ }^{90}$

\section{Conclusions}

This investigation concludes that Bearded Reedlings are becoming to be stronger and smaller on time and overwhelmed by increments of some climatic variables examined. In addition, this effect is agedependent ${ }^{28}$ in the form that youngsters improve condition and adults impair it. This adaption could force dispersal of birds towards novel habitats since observations at nearby and semi-distant areas have been reported. Management of cleared and dense reebeds at intermediate areas is fundamental to favour displacements due to the strong requirements of this species for good masses of reed. Further fine studies are need to study these aspects at isolated and decreasing populations across Europe ${ }^{12,81,82}$ to implement management and conservation measures of this species to avoid its extinction. ${ }^{83-90}$

\section{Acknowledgments}

I thank to Comunidad de Riegos de Levante and Generalitat 
Valenciana for the permissions to ring at "El Hondo Natural" Park during the study period. Raül Aymí from Instituto Catalán de Ornitología provided me with some bibliographic references. The Estación Experimental Agraria (Generalitat Valenciana) of Elche (Alicante) provided me with the meteorological data. I kindly acknowledge the tasks of peers of peerage of science in the first step on the manuscript evaluation.

\section{Conflicts of interest}

The author declares there is no conflicts of interest.

\section{References}

1. Hoi H, Hoi Ch. Intrasexual selection in Bearded Tits: Beard length - a reliable predictor for dominance rank. In: Hoi H, editor. The ecology of reed birds. Biosystematics and Ecology Series. 2001;18:121-138.

2. Romero Pujante MD, Hoi H, Blomqvist D. The importance of tail length for habitat use in the Bearded Tit Panurus biarmicus: an experimental study. IBIS. 2005;147(3):464-470.

3. Kumberloeve H. Sur la situation subespecifique des Mesànges à moustaches (Panurus biarmicus) en Asia Minuere et les alentours. Aves. 1969;6(2):61.

4. Sluys K. Bearded Tits (Panurus biarmicus) in the Netherlands and England: comments on hibridization theory. Journal of Ornithology. 1982;123(2):175-182.

5. Cramp S, Perrins CM. The Birds of the Western Palearctic. Vol VII. Oxford University Press. Oxford. 1993.

6. Erard Ch. Invasion de Mèsanges à moustaches (Panurus biarmicus L). Alauda. 1966;34:240-242.

7. Mead CJ, Pearson DJ. Bearded Reedling populations in England and Holland. Bird Study. 1974;21:211-214.

8. Loison M, Godin J. Presence estivale de la Mesànge à moustaches (Panurus biarmicus) en Hainaut occidental. Aves. 1975;12(1):31-32.

9. Olsson V. Bearded Reedling populations in Scandinavia. Bird Study. 1975;22:116-117.

10. Antoniazza M, Levéque R. La Mésange à moustaches (Panurus biarmicus), une nouvelle espéce nicheuse de l'avifaune suisse. Nos Oiseaux. 1977;34:93-110.

11. European bird population: estimates and trends. Birdlife International Conservation Series no.10, Cambridge. 2000.

12. CAM van Turnhout, Hagemeijer EJM, Foppen RPB. Long-term population developments in typical marshland birds in The Netherlands. Ardea. 2010;98(3):283-299.

13. López G, Monrós J. Bigotudo (Panurus biarmicus). In: Madroño A, González C, et al. editors. Libro Rojo de las Aves de España. Madrid. 2004.

14. Peiró IG, Robledano F, Esteve MA. Revisión de los estados de conservación del Bigotudo Panurus biarmicus a escala nacional, regional y local. El Serenet. 2010;7:29-35.

15. Martínez I, Elliott A. Mallerenga de bigotis Panurus biarmicus. In: Estrada J, Pedrocchi V, et al. editors. Atles dels ocells nidificants de Catalunya 1999-2002. 2004;450-451.

16. López G, Belenguer R, Castany J, et al. El declive del bigotudo en la Comunidad Valenciana. Quercus. 2007;262:14-18.

17. Belenguer R, López G, Dies JI, et al. Dramatic decline of the bearded reedling Panurus biarmicus in Spanish Mediterranean wetlands. Animal Biodiversity and Conservation. 2016;39(1):19-27.
18. Wilson J, Peach W. Impact of an exceptional winter flood on the population dynamics of bearded tits (Panurus biarmicus). Animal Conservation. 2006;9(4):463-473.

19. Beemster N, Troost E, Platteeuw M. Early successional stages of Reed Phragmites australis vegetations and its importance for the Bearded Reedling Panurus biarmicus in Oostvaardersplassen, The Netherlands. Ardea. 2010;98(3):339-354.

20. Surmacki A, Stepniewski J. Do weather conditions affect the dynamics of bearded tits Panurus biarmicus populations throughout the year? A case study from western Poland. Ann Zool Fennici. 2007;44(1):35-42.

21. Peiró IG, Maciá ML. Evolución de la abundancia del Bigotudo Panurus biarmicus en carrizales del Parque Natural de El Hondo (SE de España). Revista Catalana de Ornitología. 2002;19:11-16.

22. Brichetti P, Grattini N. Distribuzione, consistenza ed evoluzione delle popolazioni di basettino Panurus biarmicus nidificanti in Italia nel periodo 1980-2006. Avocetta. 2008;32:47-53.

23. Piersma T, Davidson NC. Confusions of mass and size. Auk. 1991;108:441-443.

24. Labocha MK, Hayes JP. Morphometric indices of body condition in birds: a review. Journal of Ornithology. 2012;153(1):1-22.

25. Labocha MK, Schutz H, Hayes JP. Which body condition index is best? Oikos. 2014;123(1):111-119.

26. Pauliny A, Wagner RH, Augustin J, et al. Age independent telomere length predicts fitness in two bird species. Mol Ecol. 2006;15(6):1681-1687.

27. Ringsby TH, Jensen H, Pärn H, et al. On being the right size: increased body size is associated with reduced telomere length under natural conditions. Proc Biol Sci. 2015;282(1820):2015-2331.

28. Piliczewski P, Jankowiak L, Wysocki D. Age dependent changes in biometrics indicate senescence in the European Blackbird Turdus merula. Bird Study. 2018;65(2):219-224.

29. Merilä J, Svensson E. Are fat reserves in migratory birds affected by condition in early life? Journal of Avian Biology. 1997;28(4):279-286.

30. Siefferman L, Hill GE, Dobson FS. Ornamental plumage coloration and condition are dependent on age in eastern bluebirds Sialia sialis. Journal of Avian Biology. 2005;36(5):428-435.

31. Norte AC, Ramos AJ, Sousa JP, et al. Variation of adult Great Tit Parus major body condition and blood parameters in relation to sex, age, year and season. Journal of Ornithology. 2009;150:651.

32. Svensson L. Identification Guide to European Passerines. 3th edn. Lars Svensson,Stockholm. 1992.

33. Gosler AG, Greenwood JJD, Baker JK, et al. The field determination of body size and condition in passerines: a report to the British Ringing Committee. Bird Study. 1998;45(1):92-103.

34. Peig J, Green AJ. The paradigm of body condition: a critical reappraisal of current methods based on mass and length. Functional Ecology. 2010;24(6):1323-1332.

35. Gaston KJ, Blackburn TM. Birds, body size and the threat of extinction. Phil Trans Roy Soc London B. 1995;347(1320):205-212.

36. Pascual J, Senar JC. What are different biometric measurements of avian body size actually measuring? Butlletí del Grup Català d'Anellament. 1996;13:1-8.

37. Senar JC, Pascual J. Keel and tarsus length may provide a good predictor of avian body size. Ardea. 1997;85:269-274.

38. Peiró IG, Robledano F, Esteve MA. The effect of age and sex on wing morphology and body size of the Bearded Tit Panurus biarmicus in relation to complete moult. Ringing \& Migration. 2006;23(2):101-106. 
39. Surmacki A, Stepniewski J, Stepniewska M. Juvenile sexual dimorphism, dichromatism and condition-dependent signaling in a bird species with early pair bonds. Journal of ornithology. 2015;156(1):65-73.

40. Darolová A, Krištofík J, Hoi H. Extreme brood sex ratios in Bearded Tits Panurus biarmicus. Ibis. 2009;151(1):191-195.

41. Hoi H, Hoy Leitner M. An alternative route to coloniality in the Bearded Tit: females pursue extra-pair fertilizations. Behavioural Ecology. 1997;8(2):113-119.

42. Peiró IG. Estudios ornitológicos basados en la gestión del hábitat de los Passeriformes del carrizal en el Parque Natural de El Fondo (Alicante, SE de España). PhD Thesis. University of Murcia. 2006.

43. Gosler A, Mogyorósi D. Bearded Tit. In: Hagenmeijer EJ, Blair MJ, editors. The EBCC Atlas of European Breeding Birds: Their Distribution and Abundance. London. 2015.

44. Perennou C, Beltrame C, Guelmami A, et al. Existing areas and past changes of wetland extent in the Mediterranean region: an overview. Ecologia mediterránea. 2012;38(2):53-66.

45. Navarro JD. Estudio ornitológico de "El Hondo”. Caja de Ahorros del Mediterráneo, Alicante. 1988.

46. Robledano F, Calvo JF, Esteve MA, et al. Estudios ecológicos de los humedales costeros del sudeste Español. II. Evolución histórica, situación actual y perspectivas de conservación. Anales de Biología. 1991;17:165176

47. Navarro JD. Notas preliminares sobre aves acuáticas de las salinas de Santa Pola (Alicante). Ardeola. 1971;15:91-93.

48. Navarro JD. Panorama ornitológico de los embalses de El Hondo (Alicante). Ardeola. 1972;16:228-239.

49. Revisión del estado de conservación de los humedales Ramsar en España Technical Research Report. SEO/Birdlife, Madrid. 2012.

50. Estado de los Humedales Ramsar en España de interés para las aves acuáticas. Technical Research report. SEO/Birdlife, Madrid. 2017.

51. Peiró IG. Resultados de las actividades de anillamiento de aves en el Parque Natural del Hondo (SE de España) durante el periodo 1991-1996. Oxyura. 1997;9:125-134.

52. Frías O, Serradilla AI, Escudero E. Informe de las actividades de la central de anillamiento de aves ICONA Año 2006. Ecología. 2007;21:209-302.

53. Peiró IG. The behavioural ecology, local population dynamics and conservation of the Bearded Reedling Panurus biarmicus in "El Hondo Natural Park"(SE Spain). Ecology and Evolutionary Biology. 2017;2(2):25-33.

54. Wilson J, Hartley IR. Changes in eye colour of juvenile Bearded Tit Panurus biarmicus and its use in determining breeding productivity. Ibis 2007;149(2):407-411.

55. Calvo JF, Hernández Navarro AJ, Robledano F, et al. Catálogo de las aves de la Región de Murcia (España). Anales de Biología. 2017;39:7-33.

56. Przybylo R, Sheldon BC, Merilä J. Climatic effects on breeding and morphology: evidence for phenotypic plasticity. Journal of Animal Ecology. 2000;69(3):395-403.

57. Mac Cullagh P, Nelder JA. Generalized Linear Models. Chapmann \& Hall. Florida. 1989

58. SPSS Reference Guide. SPSS Inc. Chicago. 2000

59. Engqvist L. The mistreatment of covariate interaction terms in linear model analyses of behavioural and evolutionary ecology studies. Animal Behaviour. 2005;70(4):967-971.
60. Schielzeth H. Simple means to improve the interpretability of regression coefficients. Methods in Ecology and Evolution. 2010;1(2):103-113.

61. De Castro M, Martín Vide J, Alonso S. The climate of Spain: past, present and scenarios for the $21^{\text {st }}$ century. A preliminary general assessment of the impacts in spain due to the effects of climate change. Spanish Ministry of Environment, Madrid. 2005

62. Peiró IG. Sex ratio variation in the Bearded Tit Panurus biarmicus in El Hondo Natural Park (SE Iberia). Revista Catalana d'Ornitologia. 2011;27:40-44

63. Laskemoen T, Fossøy F, Rudolfsen G, et al. Age-related variation in primary sexual characters in a passerine with male age-related fertilization success, the bluethroat Luscinia svecica. Journal of Avian Biology. 2008;39(3):322-328.

64. Freeman Gallant CR, Taff CC, Morin DF, et al. Sexual selection, multiple male ornaments, and age-and condition-dependent signaling $\mathrm{n}$ the common yellowthroat. Evolution. 2009;64(4):1007-1017.

65. Pérez KO, Munch SB. Extreme selection on size in the early lives of fish Evolution. 2010;64(8):2450-2457.

66. Grunst AS, Rotenberry JT, Grunst M L. Age-dependent relationships between multiple sexual pigments and condition in males and females. Behavioral Ecology. 2014;25(2):276-287.

67. Vedder O, Bouwhuis S, Sheldon BC. Quantitative assessment of the importance of phenotypic plasticity in adaptation to climate change in wild bird populations. PLoS Biology. 2013;11(7):1001605.

68. Yom Tov Y. Global warming and body mass decline in Israeli passerine birds. Proc Biol Sci. 2001;268(1470):947-952.

69. Yom Tov Y, Yom Tov S, Wright J, et al. Recent changes in body weight and wing length among some British passerine birds. Oikos. 2006;112(1):91101.

70. Bibby CJ, Thomas DK. Breeding and diets of the Reed Warbler at a rich and a poor site. Bird Study. 1985;32(1):19-31.

71. Peiró IG. Movements, sex-ratios, recovery rates and longevity of the Bearded Reedling Panurus biarmicus in Iberia. Ringing \& Migration. 2013;28(1):50-52.

72. Tellería JL, Santos T. Factors involved in the distribution of forest birds in the Iberian Peninsula. Bird Study. 1994;41(3):161-169.

73. Jiménez J, Moreno Opo R, Carrasco M, et al. Estimating the abundance and habitat selection of conservation priority marsh-dwelling passerines with a double-observer approach. Ardeola. 2015;62(2):269-281.

74. Kingsolver JG, Huey RB. Size, temperature, and fitness: three rules. Evolutionary Ecology Research. 2008;10:251-268.

75. Gardner JL, Peters A, Kearney MR, et al. Declining body size: a third universal response to warming? Trends in ecology \& evolution. 2011;26(6):285-291.

76. Sheridan JA, Bickford D. Shrinking body size as an ecological response to climate change. Nature climate change. 2011;1:401-406.

77. Hamilton TH. The adaptive significances of intraspecific trends of variation in wing length and body size among bird species. Evolution. $1961 ; 15(2): 180-195$.

78. Blackburn TM, Gaston KJ, Loder N. Geographic gradients in body size: a clarification of Bergmann's rule. Diversity and distributions. 1999;5(4):165-174.

79. Björklund M, Borras A, Cabrera J, et al. Increase in body size is correlated to warmer winters in a passerine bird as inferred from time series data. Ecol Evol. 2015;5(1):59-72. 
80. Hoi H. Ökologie und Paarungssystem der Bartmeise (Panurus biarmicus). $\mathrm{PhD}$ Thesis. University of Vienna. 1989.

81. Antón AG, Garza V, Traba J. Climate, isolation and intraspecific competition affect morphological traits in an endangered steppe bird, the Dupont's Lark Chersophilus duponti. Bird Study. 2018;65(3):373-384.

82. Marin G, Marchesini M, Tiloca G, et al. DNA fingerprinting fails to reveal inbreeding in a small, closed population of Bearded Tits (Panurus biarmicus L.). Ethology, Ecology and Evolution. 1994;6(2):243-248.

83. Saygili F, Yigit N, Cam P, et al. Morphometric and allozymic differences between Bearded Tit Panurus biarmicus (Aves: Passeriformes) subpopulations in a large wetland and a small pond in central Anatolia, Turkey. Turkish Journal of Zoology. 2013;37:149-156.

84. Peiró IG. Bigotudo (Panurus biarmicus). In: Díes JI, Díes B, editors. Anuario Ornitológico Comunidad Valenciana. Valencia. 1992.

85. Malzer I. Patterns in the space use of the Bearded Reedling, Panurus biarmicus, on the Tay Reedbeds, Scotland. PhD thesis. University of Glasgow. 2017.
86. Alcaráz LR, Gil Delgado JA. Aves nidificantes de la provincia de Alicante. Instituto de Cultura Juan Gil Albert, Alicante. 1986.

87. Villarán A, Pascual Parra J. Recapture rates of five passerine species wintering at a reedbed in central Spain. Revista catalana d'ornitologia. 2003;20:19-27.

88. Marchant JH. Recent trends in breeding populations of some common trans-Saharan migrant birds in northern Europe. Ibis. 1992;134(1):113119.

89. Major RE, Johnson RN, King AG, et al. Genetic isolation of endangered bird populations inhabiting salt marsh remnants surrounded by intensive urbanization. Animal conservation. 2014;17(5):419-429.

90. Bouwhuis S, Sheldon BC, Verhulst S, et al. Great tits growing old: selective disappearance and the partitioning of senescence to stages within the breeding cycle. Proc Biol Sci. 2009;276(1668):2769-2777. 